\title{
Toll-like receptor 2 and 9 are expressed and functional in gut-associated lymphoid tissues of presuckling newborn swine
}

\author{
Masanori TOHNO a,b , Takeshi SHIMOSATO ${ }^{\mathrm{a}}$, Masayuki MouE ${ }^{\mathrm{a}}$, \\ Hisashi ASO $^{\mathrm{c}}$, Kouichi WATANABE ${ }^{\mathrm{c}}$, Yasushi KAWAI ${ }^{\mathrm{a}}$, \\ Takahiro YAMAGUCHI $^{\mathrm{c}}$, Tadao SAITO ${ }^{\mathrm{a}}$, Haruki KITAZAWA ${ }^{\text {a* }}$ \\ ${ }^{a}$ Laboratory of Animal Products Chemistry, Graduate School of Agricultural Science, \\ Tohoku University, Aobaku, Sendai, 981-8555, Japan \\ b JSPS Research Fellow, Graduate School of Agricultural Science, Tohoku University, Aobaku, \\ Sendai, 981-8555, Japan \\ ${ }^{\mathrm{c}}$ Laboratory of Functional Morphology, Graduate School of Agricultural Science, Tohoku University, \\ Aobaku, Sendai, 981-8555, Japan
}

(Received 8 March 2006; accepted 10 May 2006)

\begin{abstract}
To clarify the crucial role of Toll-like receptor (TLR) 2 and TLR9 in immature gutassociated lymphoid tissues (GALT), we focused on the expression of TLR2 and TLR9 and the immune responses induced by their ligands in the GALT of presuckling newborn swine. Quantitative real-time PCR revealed that TLR2 and TLR9 mRNA were expressed at detectable levels in all tested tissues (heart, thymus, lung, spleen, liver, kidney, skeletal muscle, duodenum, jejunum, ileum, ileal Peyer patches (Pps), and mesenteric lymph nodes (MLN)). In particular, in immature intestinal tissues and GALT, TLR2 and TLR9 mRNA were expressed at higher levels in ileal Pps and MLN than in the duodenum, jejunum, and ileum. We confirmed that the TLR2 and TLR9 proteins were also highly expressed and that their ligands were preferentially recognized by TLR2- or TLR9-expressing cells in the MLN and ileal Pps. Zymosan, CpG2006, and lactic acid bacteria could promote mitogenesis and production of multiple cytokines by the MLN and ileal Pps. In addition, double immunostaining for cytokeratin 18 and either TLR2 or TLR9 revealed that both TLR2 and TLR9 are strongly expressed in the columnar membranous (M) cells. Interestingly, while the apical membrane of the columnar M cells strongly expressed TLR2 protein and preferentially recognized zymosan, both "TLR2 expression on the apical membrane" and "TLR2-mediated zymosan binding" were negligible in neighboring enterocytes. These results indicate that TLR2 and TLR9 allow MLN and ileal Pps to respond to a variety of bacterial components immediately after birth, thereby providing newborns with a host defense system.
\end{abstract}

Toll-like receptor 2 / Toll-like receptor 9 / membranous cells / gut-associated lymphoid tissues / newborn swine

\footnotetext{
*Corresponding author: haruki@bios.tohoku.ac.jp
} 


\section{INTRODUCTION}

The gut-associated lymphoid tissues (GALT) consists of scattered effector lymphocytes and organized inductive sites, namely the mesenteric lymph nodes (MLN) and Peyer patches (Pps). These tissues provide a barrier against the invasion of host tissues by both pathogenic and nonpathogenic bacteria [32]. Because microbial antigens are separated from the body by only a single epithelial cell layer, microbial stimuli including immunobiotics [9] can influence gut-associated immunological homeostasis.

Most allergic diseases reflect an imbalance between T-helper (Th) 1 and 2 cells in lymphocyte-mediated immunity [31]. The bacteria encountered after birth are thought to constitute the major trigger for a shift away from the predominant Th2-mediated newborn immune system towards a Th1mediated system that is less susceptible to allergens [4]. Indeed, a relationship between the intestinal microflora and the development of allergies has been proposed based on differences in the composition of the intestinal microflora in allergic and nonallergic infants $[18,19]$. Despite this correlation, the molecular mechanism for the recognition of various microbial molecules in the immature GALT of newborns remains unclear.

In the host-microbe interaction, monocytes and macrophages along with dendritic cells play a crucial role in the innate immune responses against pathogen-associated molecular patterns (PAMP) [30]. PAMP are produced by microorganisms and often play an important role in bacterial structure. They activate the host immune system through a process mediated by Toll-like receptors (TLR). The TLR signaling pathways lead to activation of a variety of transcription factors such as nuclear factor- $\kappa \mathrm{B}(\mathrm{NF}-\mathrm{\kappa B})$, which triggers the production of Th1 and/or Th2-cytokines. Examples of PAMP include cellular components such as zymosan and DNA motifs, which have been shown to activate TLR2 and TLR9 signaling pathways, respectively [46]. In previous studies, we showed that the PAMP from lactic acid bacteria (LAB) (e.g., cell wall components, extracellular phosphopolysaccharide, and $\mathrm{CpG}$ or non-CpG DNA motifs) have immunostimulatory activities, including augmentation of mitogenic activity, up-regulation of costimulatory molecule expression, and induction of cytokine production $[17,23,24,35,45]$. Furthermore, in recent studies, we revealed that immunobiotic $\mathrm{LAB}$ and their $\mathrm{CpG}$ or non-CpG DNA motifs are recognized by TLR2 and TLR9, respectively, and we also confirmed that NF- $\kappa B$ is activated in TLR2- or TLR9expressing transfectants [37-39, 47]. More recently, TLR2 and TLR9, which participate in the recognition of LAB components, were found to be preferentially expressed in adult swine GALT [40, 48]. Although the expression patterns of TLR2 and TLR9, and the biological effects of their ligands (e.g., CpG-DNA and cell wall components) and $\mathrm{LAB}$ in adult swine have been characterized [20, 40, 48, 51], there is less information about the molecular pathways through which TLR2 and TLR9 mediate innate immunity in the immature GALT of newborn swine. This information is of value for understanding host defense in newborn humans and animals.

In recent years, there has been a growing interest in the swine immune system because of its possible use as a model for the human immune system and because of the economic importance of swine as livestock $[14,16]$. In addition, with respect to digestion, the swine gastrointestinal tract has many structural aspects that are more similar to the human system than the rodent system. Therefore, investigating how TLR mediate microbial stimulation of the GALT in newborn swine is important for understanding the activation 
and development of the immune system in newborn humans.

In the present study, we measured the expression of TLR2 and TLR9 mRNA in various newborn swine tissues. Using immunohistochemistry and flow cytometry, we also analyzed the functional expression of TLR2 and TLR9 proteins as well as the receptor binding of their ligands in the GALT of presuckling newborn swine. Furthermore, we showed that TLR2 and TLR9 ligands as well as LAB induce certain immune responses, including augmentation of mitogenic activity and induction of cytokine production, immediately after birth. These results suggest that TLR2 and TLR9 play a critical role even in the immature GALT of healthy presuckling newborn swine, information that is helpful for understanding the role of these receptors in newborn humans.

\section{MATERIALS AND METHODS}

\subsection{Experimental tissues}

Experimental tissues (heart, thymus, lung, spleen, liver, kidney, skeletal muscle, duodenum, jejunum, ileum, ileal Pps, and MLN) were immediately prepared from newborn LWD swine ( $n=9$; genotype 1/2 Duroc, 1/4 Landrace, 1/4 Large White; age 0 days; Hiruzu Co., Ltd., Miyagi, Japan) that had not received colostrum. Intestinal tissues and GALT from newborn swine were prepared as described previously [42]. The swine were clinically healthy and free of infectious diseases. The present study was conducted in accordance with the Guidelines for Animal Experimentation of Tohoku University, Japan.

\subsection{LAB}

Lactobacillus (L.) delbrueckii ssp. bulgaricus and L. gasseri, which are two species of LAB, were tested in this study.
L. bulgaricus NIAI B6 was obtained from the National Institute of Animal Industry (Tukuba, Japan). L. gasseri JCM1131 ${ }^{\mathrm{T}}$ was purchased from the Japan Collection of Microorganisms (Saitama, Japan). All strains were cultured at $37^{\circ} \mathrm{C}$ for $16 \mathrm{~h}$ in Man Rogosa Sharpe broth (Difco, Detroit, MI, USA), lyophilized, and killed by heat treatment for $30 \mathrm{~min}$ at $56{ }^{\circ} \mathrm{C}$.

\subsection{Quantitative expression analysis by real-time polymerase chain reactions (PCR)}

Total RNA was isolated from various newborn swine tissues as described previously $[40,48]$. Briefly, cDNA were prepared by reverse transcription of $1 \mu \mathrm{g}$ total RNA using Oligo d(T) 18 primer (Invitrogen, Carlsbad, CA, USA). An equivalent volume of cDNA solution $(5 \mu \mathrm{L})$ from each sample was used for quantification of swine TLR2- or TLR9-specific cDNA by real-time quantitative PCR. The real-time quantitative PCR reactions were performed on a LightCycler using FastStart DNA Master SYBR Green I mixture (Roche, Mannheim, Germany) and the following primers: swine TLR2, 5'-ACA TGA AGA TGA TGT GGG CC-3' (sense) and $5^{\prime}$-TAG GAG TCC TGC TCA CTG TA-3' (antisense) [48]; swine TLR9, 5'GTG GAA CTG TTT TGG CAT C-3' (sense) and 5'-CAC AGC ACT CTG AGC TTT GT-3' (antisense) [40]; and swine $\beta$ actin, $5^{\prime}$-CAT CAC CAT CGG CAA CGA$3^{\prime}$ (sense) and 5'-GCG TAG AGG TCC TTC CTG ATG T-3' (antisense). PCR was carried out with an initial denaturation for $10 \mathrm{~min}$ at $95^{\circ} \mathrm{C}$, followed by 45 cycles of $15 \mathrm{~s}$ at $95{ }^{\circ} \mathrm{C}, 10 \mathrm{~s}$ at $60{ }^{\circ} \mathrm{C}$, and $5 \mathrm{~s}$ at $72{ }^{\circ} \mathrm{C}$. The results are expressed as the relative mRNA index, which was calculated as the mRNA index (TLR mRNA copy number/ $\beta$-actin mRNA copy number) for the test sample divided by the mRNA index in the spleen. In the control tubes, poly 
$(\mathrm{A})^{+}$RNA samples were used as templates to check for the presence of contaminating genomic DNA. Amplification products of contaminants such as primer dimers were not detected by SYBR green chemistry using serial dilutions of cDNA. DNA sequencing confirmed that the amplified cDNA were identical to bases 1852 to 1961 of swine TLR2 and bases 2496 to 2694 of swine TLR9, respectively.

\subsection{Polyclonal antibodies $(\mathrm{Ab})$ to swine TLR2 and TLR9}

The anti-swine TLR2 and TLR9 polyclonal $\mathrm{Ab}[40,48]$ were generated in our previous studies. Briefly, peptides corresponding to residues 76 to 90 (CVNLRALRLGANSIH) of the swine TLR2 extracellular domain and 269 to 285 (CPKDHPKLHSDTFSHLS) of the swine TLR9 extracellular domain were synthesized, emulsified at a 1:1 ratio (v/v) with Freund Complete Adjuvant, and injected into Japanese white rabbits. After two boosters at monthly intervals, the rabbits were bled, and the antisera were collected and purified by epitope affinity chromatography.

\subsection{Immunohistochemical analysis}

Immunohistochemical analysis was conducted according to our previous reports $[40,48]$. Swine were sacrificed, and fresh ileal Pps and MLN were prepared, washed with phosphate-buffered saline (PBS), cut into small pieces $(5 \mathrm{~mm} \times$ $10 \mathrm{~mm}$ ), and fixed in Zamboni fixative $(0.2 \%$ saturated picric acid and $4 \%$ paraformaldehyde in $0.1 \mathrm{M}$ phosphate buffer, $\mathrm{pH}$ 7.4) for $16 \mathrm{~h}$ at $4{ }^{\circ} \mathrm{C}$ [44]. The fixed tissues were washed for $24 \mathrm{~h}$ with $1 \%$ arabic gum in $0.1 \mathrm{M}$ phosphate buffer containing $8 \%$ sucrose and once for $24 \mathrm{~h}$ with the same solution containing $16 \%$ sucrose. The washed samples were then immersed in TISSUE TEKO.C.T. compound (Sakura Finetechnical, Tokyo, Japan) and quickly frozen in a dry ice/acetone bath. Cryostat sections (10 $\mu \mathrm{m}$ thickness) were prepared from the frozen tissues that were then mounted on poly-L-lysine-coated glass slides, and washed in PBS. The sections were incubated for $20 \mathrm{~min}$ with $1 \%$ bovine serum albumin and $2 \%$ normal goat serum (Vector Laboratories, Burlingame, CA, USA) in PBS at room temperature to block nonspecific binding sites. After removal of the blocking solution, sections were incubated for $16 \mathrm{~h}$ at $4{ }^{\circ} \mathrm{C}$ in a humidified chamber with 1:600 anti-swine TLR2 polyclonal $\mathrm{Ab}$ or 1:1000 anti-swine TLR9 polyclonal $\mathrm{Ab}$. After washing three times with PBS, sections were incubated for $30 \mathrm{~min}$ at room temperature with 1:1000 Alexa 488-conjugated goat anti-rabbit IgG (Molecular Probes, Eugene, OR, USA).

Double immunostaining for cytokeratin 18, a marker for swine membranous (M) cells, and either TLR2 or TLR9 was performed on cryostat sections of ileal Pps. Briefly, the sections were washed in $0.05 \mathrm{M}$ Tris- $\mathrm{HCl}(\mathrm{pH} \mathrm{7.6)}$ for $5 \mathrm{~min}$ and then treated for $3 \mathrm{~min}$ with $0.03 \%$ pronase E (Kaken Pharmaceutical, Tokyo, Japan) in the same buffer to retrieve antigen expression of cytokeratin 18. After washing in PBS, the sections were incubated for $20 \mathrm{~min}$ with $1 \%$ bovine serum albumin and 2\% normal goat serum in PBS at room temperature, followed by $16 \mathrm{~h}$ with 1:1600 anti-cytokeratin 18 monoclonal Ab (mAb) (clone CY-90; SigmaAldrich, St. Louis, MO, USA) in PBS for $16 \mathrm{~h}$ in a humidified chamber at $4{ }^{\circ} \mathrm{C}$. The sections were washed again in PBS and incubated for $30 \mathrm{~min}$ at room temperature with 1:1000 Alexa 647-conjugated goat anti-mouse IgG (Molecular Probes). The cytokeratin 18-immunoreactive cells were stained with 1:600 anti-swine TLR2 polyclonal $\mathrm{Ab}$ or 1:1000 anti-swine TLR9 
polyclonal $\mathrm{Ab}$, followed by 1:1000 Alexa 488-conjugated goat anti-rabbit IgG.

While protecting the sections from direct exposure to light, they were washed three times in PBS and then stained with SYTOX orange (Molecular Probes) to detect nuclei. Finally, the specimens were washed three times in PBS, mounted in PermaFluor (Immunon, Pittsburgh, PA, USA), and observed under a MRC-1024 confocal laser scanning microscope (BioRad, Richmond, CA, USA). Control experiments were performed by omitting primary $\mathrm{Ab}$. The specificity of the positive staining of swine TLR2 and TLR9 was determined by a preabsorption study in which the primary $\mathrm{Ab}$ were incubated with the corresponding antigen for $48 \mathrm{~h}$ at $4{ }^{\circ} \mathrm{C}$ before application to the sections.

Immunohistochemical and immunoblotting studies have demonstrated that the cytokeratin $18 \mathrm{mAb}$ is specific [13]. Especially, the $\mathrm{mAb}$ can recognize the cytokeratin 18 in the swine $M$ cells because the $\mathrm{M}$ cells more strongly expressed the cytokeratin 18 than the neighboring enterocytes [13].

\subsection{Flow cytometric analysis}

Single-cell suspensions from ileal Pps and MLN were prepared as previously described [40, 48]. Briefly, after cutting the specimens into small fragments, they were gently pressed through a nylon mesh and washed three times in complete RPMI 1640 medium (Sigma) supplemented with $10 \%$ fetal calf serum (FCS) (Sigma). Residual erythrocytes were lysed by resuspension in hypotonic salt solution $(0.2 \% \mathrm{NaCl})$, followed by hypertonic rescue in an equal volume of $1.5 \% \mathrm{NaCl}$. After washing three times with a staining buffer (PBS containing 2\% FCS and $0.1 \%$ sodium azide), the cells were treated with $2 \mathrm{mg} / \mathrm{mL}$ collagenase (Wako, Osaka, Japan) and $0.1 \mathrm{mg} / \mathrm{mL}$ dispase (Sigma) for $30 \mathrm{~min}$ at $25{ }^{\circ} \mathrm{C}$, after which they were passed through cell strainers (BD bioscience, Tokyo, Japan) to remove debris and connective tissue.

The cells $\left(2 \times 10^{6}\right)$ were incubated with $1 \mu \mathrm{M}$ Fluorescein isothiocianate (FITC)conjugated CpG2006 (Operon, Tokyo, Japan) which has been identified as an optimal ligand for human and swine TLR9 $[15,39,41]$ or $10 \mu \mathrm{g} / \mathrm{mL}$ FITCconjugated zymosan (Molecular Probes) which is a ligand for TLR2 [47] for $1 \mathrm{~h}$ at $37{ }^{\circ} \mathrm{C}$ in an atmosphere containing $5 \% \mathrm{CO}_{2}$. After washing three times with a staining buffer, the cells obtained from MLN were incubated for $1 \mathrm{~h}$ at $4{ }^{\circ} \mathrm{C}$ with anti-swine TLR2 polyclonal $\mathrm{Ab}$ or antiswine TLR9 polyclonal Ab. After washing three times with staining buffer, the cells were incubated for $30 \mathrm{~min}$ at $4{ }^{\circ} \mathrm{C}$ with Phycoerythrin-Cyanine-5 (PE-Cy5)conjugated goat anti-rabbit $\mathrm{IgG}$ at 1:100 (Santa Cruz Biotechnologies, Santa Cruz, CA, USA). For dual staining of the cells from ileal Pps, they were incubated with anti-cytokeratin $18 \mathrm{mAb}$ followed by PEconjugated sheep anti-mouse IgG (Sigma) and either anti-TLR2 Ab or anti-TLR9 Ab followed by PE-Cy5-conjugated goat antirabbit IgG. The cells were analyzed on a FACSCalibur (BD bioscience). In negative controls, mouse or rabbit normal IgG (all from Santa Cruz Biotechnologies) were used as primary $\mathrm{Ab}$. To permeabilize cells, $0.3 \%$ saponin was added to the staining buffer as described previously [52]. Similar results were obtained from at least nine different newborn swine.

\subsection{Assay of lymphocyte proliferation}

Lymphocyte proliferation was assayed as previously described [41]. Briefly, the cells from ileal Pps or MLN $(n=9$; $2 \times 10^{5}$ cells/well) were placed in each well of a 96-well microplate (CorningCostar, Corning, NY, USA) in $100 \mu \mathrm{L}$ 
of complete RPMI 1640 medium supplemented with $2 \%$ FCS, $10 \mu \mathrm{M}$ CpG2006 (Operon), $10 \mu \mathrm{g} / \mathrm{mL}$ zymosan (Molecular Probes), and $100 \mu \mathrm{g} / \mathrm{mL}$ L. gasseri $\mathrm{JCM} 1131^{\mathrm{T}}$, or $100 \mu \mathrm{g} / \mathrm{mL}$ L. bulgaricus NIAI B6. The cells were grown for $48 \mathrm{~h}$ at $37{ }^{\circ} \mathrm{C}$ in an atmosphere of $5 \% \mathrm{CO}_{2}$, and test conditions were assayed in triplicate. During the final $16 \mathrm{~h}$ of culture, the cells were radiolabeled with $9.25 \mathrm{kBq} /$ well of [methyl- $\left.{ }^{3} \mathrm{H}\right]$-uridine (Amersham Life Science International, Buckinghamshire, UK). The cells were then harvested with a glass fiber filter (Packard Bioscience, Canberra, Australia), and adsorbed ${ }^{3} \mathrm{H}$ was measured with a liquid scintillation counter (Beckman Instruments, Palo Alto, CA, USA). The results are presented as the stimulation index $=($ counts per $\min (\mathrm{cpm})$ in treated cultures $-\mathrm{cpm}$ for background) $\div$ (cpm in control cultures - cpm for background). A Limulus amebocyte lysate kit (Seikagaku, Tokyo, Japan) confirmed that all test solutions were free of endotoxin.

\subsection{Measurement of cytokine production and TLR expression}

The expression of cytokines and TLR was measured by real-time quantitative PCR as previously described [41]. Briefly, total RNA was isolated from $1 \times 10^{6}$ ileal Pps and MLN cells treated with no addition, CpG2006 $(10 \mu \mathrm{M})$, zymosan $(10 \mu \mathrm{g} / \mathrm{mL})$, L. gasseri $\mathrm{JCM} 1131^{\mathrm{T}}(100 \mu \mathrm{g} / \mathrm{mL})$, or L. bulgaricus NIAI B6 $(100 \mu \mathrm{g} / \mathrm{mL})$ for $6 \mathrm{~h}$ at $37^{\circ} \mathrm{C}$ in an atmosphere of $5 \% \mathrm{CO}_{2}$. Five replicates were performed for each condition. Total RNA was treated for $10 \mathrm{~min}$ at $37^{\circ} \mathrm{C}$ with RNase-free DNase I (Roche, Lewes, UK), followed by heat inactivation for $15 \mathrm{~min}$ at $70{ }^{\circ} \mathrm{C}$. The cDNA were prepared by reverse transcription from $1 \mu \mathrm{g}$ of total RNA using oligo $\mathrm{d}(\mathrm{T})_{18}$ primer. An equivalent volume of the cDNA solution was used for measuring the levels of cytokine, TLR2, and TLR9 cDNA by real-time quantitative PCR using a 7300 Real Time PCR System (Applied Biosystems, Warrington, UK). Fluorescent real-time quantitative PCR reactions were performed using a TaqMan PCR core reagent kit (Applied Biosystems) in $25 \mu \mathrm{L}$ containing $5 \mathrm{ng}$ of cDNA and the following primers: swine IFN- $\gamma$, 5'-GCA AAG CCA TCA GTG AAC TC- $3^{\prime}$ (sense) and 5' -TCT CTG GCC TTG GAA CAT AG-3' (antisense) [41]; swine IL-12p35, 5'-AGT TCC AGG CCA TGA ATG CA-3' (sense) and 5'-TGG CAC AGT CTC ACT GTT GA-3' (antisense); swine IL-6, 5' -TGG ATA AGC TGC AGT CAC AG-3' (sense) and 5'-ATT ATC CGA AGT GCC CTC AG-3' (antisense); swine IL-10, 5'-TGG GTT GCC AAG CCT TGT-3' (sense) and 5'-GCC TTC GGC ATT ACG TCT TC-3' (antisense); swine TGF- $\beta, 5^{\prime}$-CTG GCC CTG CTG AAC TTT G-3' (sense) and 5'-AAG GTG GTG CAA GTG GAC ATG-3' (antisense); swine TLR2, 5'-ACA TGA AGA TGA TGT GGG CC-3' (sense) and 5'-TAG GAG TCC TGC TCA CTG TA-3' (antisense) [48]; swine TLR9, 5'-GTG GAA CTG TTT TGG CAT C-3' (sense) and 5'-CAC AGC ACT CTG AGC TTT GT-3' (antisense) [40]; and swine $\beta$-actin, 5'-CAT CAC CAT CGG CAA CGA-3' (sense) and 5'-GCG TAG AGG TCC TTC CTG ATG T-3' (antisense). PCR was carried out with an initial denaturation for $10 \mathrm{~min}$ at $95^{\circ} \mathrm{C}$, followed by 45 cycles of $15 \mathrm{~s}$ at $95^{\circ} \mathrm{C}$ and $60 \mathrm{~s}$ at $60{ }^{\circ} \mathrm{C}$. The results are expressed as the relative mRNA index, which was calculated as the mRNA index (cytokine or TLR mRNA copy number/ $\beta$ actin mRNA copy number) for the test sample divided by the mRNA index in unstimulated cells. In the control tubes, poly $(\mathrm{A})^{+}$RNA samples were used as templates to check for the presence of contaminating genomic DNA. Amplification products of contaminants such as primer dimers were not detected by SYBR green chemistry using serial dilutions of cDNA. 

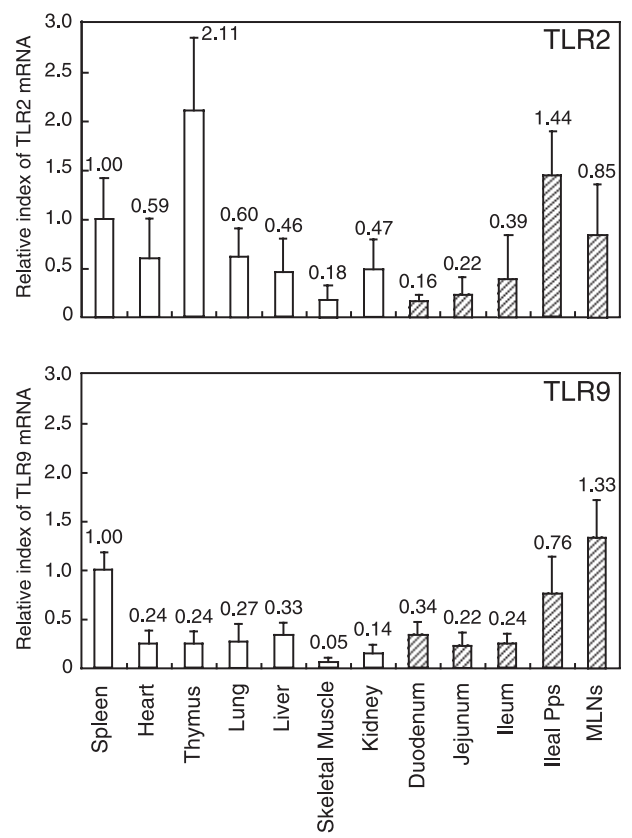

Figure 1. Analysis of TLR2 and TLR9 expression in newborn swine tissues by real-time quantitative PCR. The TLR2 and TLR9 mRNA levels were normalized by the swine $\beta$-actin level, and the relative index was determined in comparison to the TLR2 and TLR9 mRNA level in the spleen (1.00). Values represent means, and error bars indicate the standard deviations. The results are means of nine independent experiments using various tissues from at least nine different newborn swine.

DNA sequencing analysis confirmed that the amplified cDNA corresponded to the sequences of the targeted genes.

\subsection{Statistics}

All results represent the average of five to nine separate experiments. The statistical significance of differences was assessed using the Student $t$-test.

\section{RESULTS}

\subsection{Expression of TLR2 and TLR9 in newborn swine tissues}

The current studies are the first to make a quantitative comparison of the tissuespecific expression of TLR2 and TLR9
mRNA in newborn swine prior to receipt of colostrum. We used real-time quantitative PCR to analyze the expression of these mRNA in swine tissues immediately after birth.

Figure 1 shows that TLR2 and TLR9 mRNA were expressed at detectable levels in all tissues of newborn swine. The expression levels of TLR2 mRNA decreased in the following order: thymus, ileal Pps, spleen, MLN, lung, heart, kidney, liver, ileum, jejunum, skeletal muscle, and duodenum. Among the intestinal tissues and GALT, TLR2 mRNA was most strongly expressed in the ileal Pps and MLN, with lower levels found in the duodenum, jejunum, and ileum. The expression of TLR9 decreased in the following order: MLN, 
spleen, ileal Pps, duodenum, liver, lung, heart/thymus/ileum, jejunum, kidney, and skeletal muscle. TLR9 mRNA was expressed significantly in MLN and at a level 1.3-fold higher than in spleen. Except for MLN and the spleen, expression of TLR9 mRNA was higher in the ileal Pps than in the other tissues (Fig. 1).

\subsection{Distribution of TLR2 and TLR9 in newborn swine MLN and ileal Pps}

The intestinal tissues and GALT are important for establishing effective immunological responses toward intestinal microbial antigens. Quantitative real-time PCR in these tissues revealed that TLR2 and TLR9 mRNA are expressed at higher levels in the ileal Pps and MLN than in the duodenum, jejunum, and ileum. To determine which cells may contribute to initial innate immunity, we next examined the distribution of TLR 2 and TLR 9 proteins in newborn swine MLN and ileal Pps by immunohistochemistry.

Visualization of the immunohistochemical staining by confocal microscopy (Fig. 2) revealed that all of the lymphoid follicles in the MLN were primary follicles lacking germinal centers. Anti-swine TLR2-reactive cells (green fluorescence) were found inside the medullary cords and in the lymphoid follicles, which contain immune cells (Fig. 2A). A high level of TLR2 expression was also found in lymphoid follicles (Fig. 2B). On the contrary, cells strongly expressing TLR9 (green fluorescence) were observed around the lymphoid follicles in MLN (Fig. 2C). The lymphoid follicles also contained cells with moderate TLR9 expression (Fig. 2D).

We then used immunohistochemistry to determine whether TLR2 and TLR9 are already expressed in immature ileal Pps of newborn swine. Immunohistochemical analysis using an anti-swine TLR2 poly- clonal $\mathrm{Ab}$ revealed many TLR2-positive cells in the lymphoid follicles (Figs. 3A and 3B). However, TLR9-positive cells were preferentially located around the bottom of the lymphoid follicles (Figs. 3C and 3D). Also, the cells in the lymphoid follicles moderately expressed TLR9 (Fig. 3D), and the interfollicular areas contained both cells positive for TLR2 and cells positive for TLR9 (Figs. 3A and 3C).

Immunostaining was not detected in MLN or ileal Pps when the primary $A b$ were omitted (data not shown). Also, dilution of the primary $\mathrm{Ab}$ reduced the intensity of immunolabeling, suggesting that the staining with the anti-TLR2 and anti-TLR9 polyclonal Ab was specific. Preabsorption studies confirmed the specificity of both primary $\mathrm{Ab}$ (data not shown).

\subsection{Expression of swine TLR2 and TLR9 on M cells}

$\mathrm{M}$ cells in the follicle-associated epithelia (FAE) transport foreign macromolecules and microorganisms to antigenpresenting cells within and under the epithelial barrier. In the present study, immunohistochemical analysis showed that cells in the immature FAE contained TLR2 or TLR9 (Figs. 3A and 3C). To determine whether $M$ cells in newborn swine also express TLR2 and TLR9, we performed double immunofluorescent staining of frozen sections from ileal Pps using $\mathrm{Ab}$ to cytokeratin 18 and either swine TLR2 or TLR9. Figures 4A-4F show magnified views of the columnar $M$ cells in the immature FAE. A small number of $\mathrm{M}$ cells were identified with the anti-cytokeratin $18 \mathrm{mAb}$ (blue fluorescence) in the immature dome epithelium (Figs. 4B and 4E). Double immunofluorescent staining for TLR2 and cytokeratin 18 revealed that the two proteins are present in similar areas of these cells (Fig. 4C). This was also found when the cells were double-stained for TLR9 

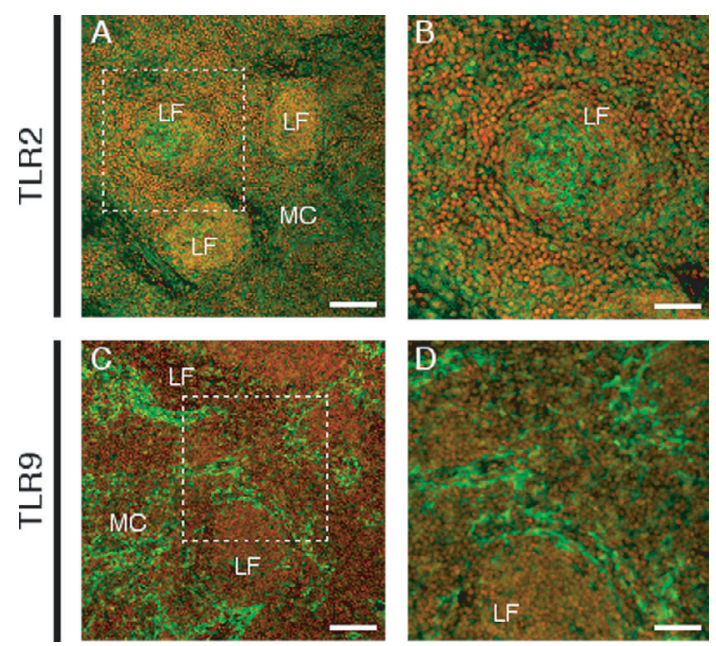

Figure 2. Immunofluorescent localization of TLR2 and TLR9 expression in longitudinal sections of newborn swine MLN. (A) Frozen sections of MLN, which include lymphoid follicle (LF) and medullary cords (MC), were incubated with an anti-swine TLR2 polyclonal Ab. The box in panel $(\mathbf{A})$ indicates the section magnified in panel $(\mathbf{B})$. Green images indicate swine TLR2 ${ }^{+}$cells. (C) Frozen sections of MLN were incubated with an anti-swine TLR9 polyclonal Ab. The box in panel $(\mathbf{C})$ indicates the section magnified in panel (D). Green images indicate swine TLR9 ${ }^{+}$. Nuclei in all panels were stained with SYTOX orange (red). Original magnification $=200 \times(\mathbf{A}, \mathbf{C})$ or $400 \times(\mathbf{B}, \mathbf{D})$. Scale bars $=50 \mu \mathrm{m}(\mathbf{A}, \mathbf{C})$ or $20 \mu \mathrm{m}(\mathbf{B}, \mathbf{D})$. The results represent nine independent experiments using MLN from at least nine different newborn swine.
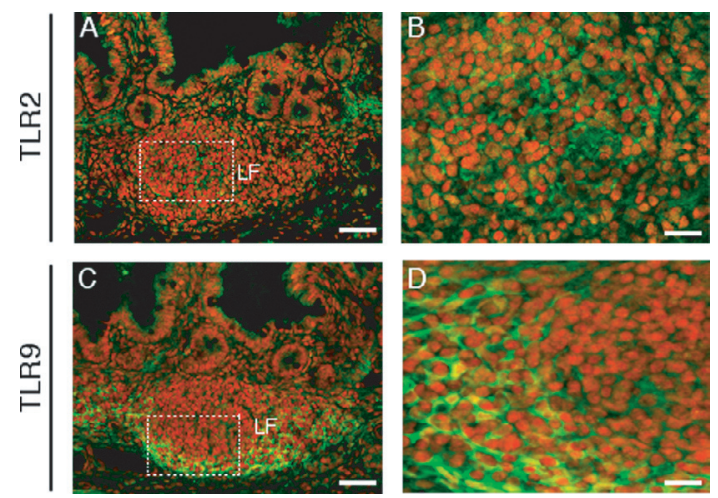

Figure 3. Immunofluorescent localization of TLR2 and TLR9 expression in longitudinal sections of newborn swine ileal Pps. (A, B) Frozen sections of ileal Pps were incubated with an anti-swine TLR2 polyclonal Ab. The box in panel (A) indicates the section magnified in panel (B). Green images indicate swine TLR2-positive cells. (C, D) Frozen sections of ileal Pps were incubated with an anti-swine TLR9 polyclonal Ab. The box in panel (C) indicates the section magnified in panel (D). Green images indicate swine TLR9-positive cells. Nuclei in all panels were stained with SYTOX orange (red). Original magnification $=400 \times(\mathbf{A}, \mathbf{C})$ or $800 \times(\mathbf{B}, \mathbf{D})$. Scale bars $=20 \mu \mathrm{m}$ $(\mathbf{A}, \mathbf{C})$ or $5 \mu \mathrm{m}(\mathbf{B}, \mathbf{D})$. LF, lymphoid follicles. The results represent nine independent experiments using ileal Pps from at least nine different newborn swine. 


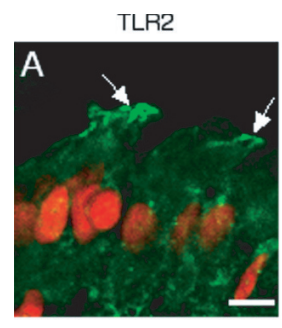

TLR9

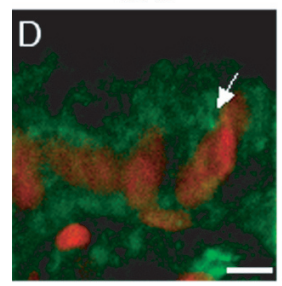

Control

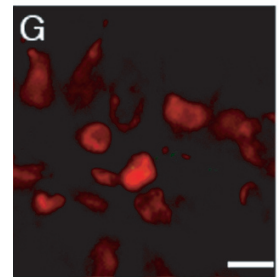

Cytokeratin 18

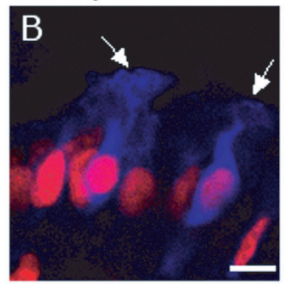

Cytokeratin 18

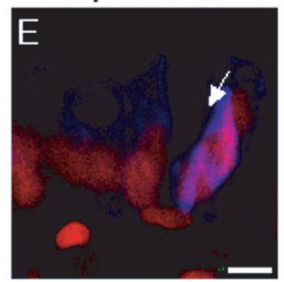

Control

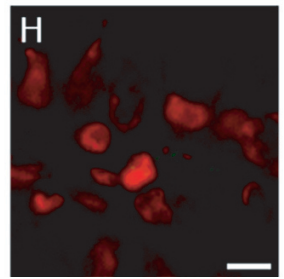

TLR2 + Cytokeratin 18

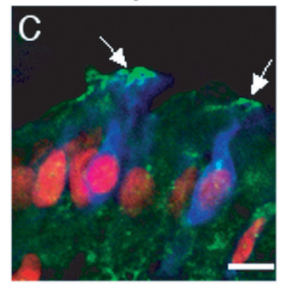

TLR9 + Cytokeratin 18

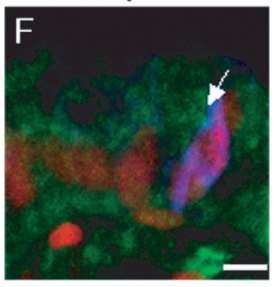

Control

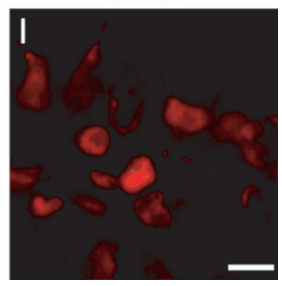

Figure 4. Newborn swine M cells express TLR2 and TLR9. Double immunohistochemical staining in the same longitudinal section of newborn swine ileal Pps with anti-swine TLR2 polyclonal Ab (green; A) or anti-swine TLR9 polyclonal Ab (green; D) and with anti-cytokeratin $18 \mathrm{mAb}$ to detect $\mathbf{M}$ cells (blue; $\mathbf{B}, \mathbf{E})$. The merged images are shown in panels $(\mathbf{C})\left(\right.$ TLR2 $-/$ cytokeratin $18^{+}$) and (F) (TLR9 $^{-}$/cytokeratin $18^{+}$). Primary Abs were omitted from control experiments in $(\mathbf{G}-\mathbf{I})$. Upper images, intestinal rumen side; lower images, lamina propria side. The arrows indicate the expression of TLR2 (A-C) and TLR9 (D-F) in newborn swine M cells. Nuclei in all columns were stained with SYTOX orange (red). Original magnification $=1000 \times$. Scale bars $=2 \mu \mathrm{m}$. The results represent nine independent experiments using ileal Pps from at least nine different newborn swine.

and cytokeratin 18 (Fig. 4F). Interestingly, TLR2 was not only expressed in the cytoplasm but also in the apical membrane of the columnar M cells (Fig. 4C). In particular, the apical membrane of the columnar M cells strongly expressed TLR2, and its expression was not observed in the neighboring enterocytes (Fig. 4C). However, this apical membrane did not express TLR9. We did not detect any immunostaining when the primary Ab were omitted (Figs. 4G-4I).

\subsection{Ligand recognition by TLR2- or TLR9-expressing cells from newborn swine MLN and ileal Pps}

We next examined the recognition of TLR2- or TLR9-expressing cells by TLR ligands. Cells were isolated from fresh newborn swine MLN and ileal Pps and examined by flow cytometry. The cells from MLN and ileal Pps were gated as one or two distinct cell populations, respectively (Figs. 5A-a and 6A-a). 
A
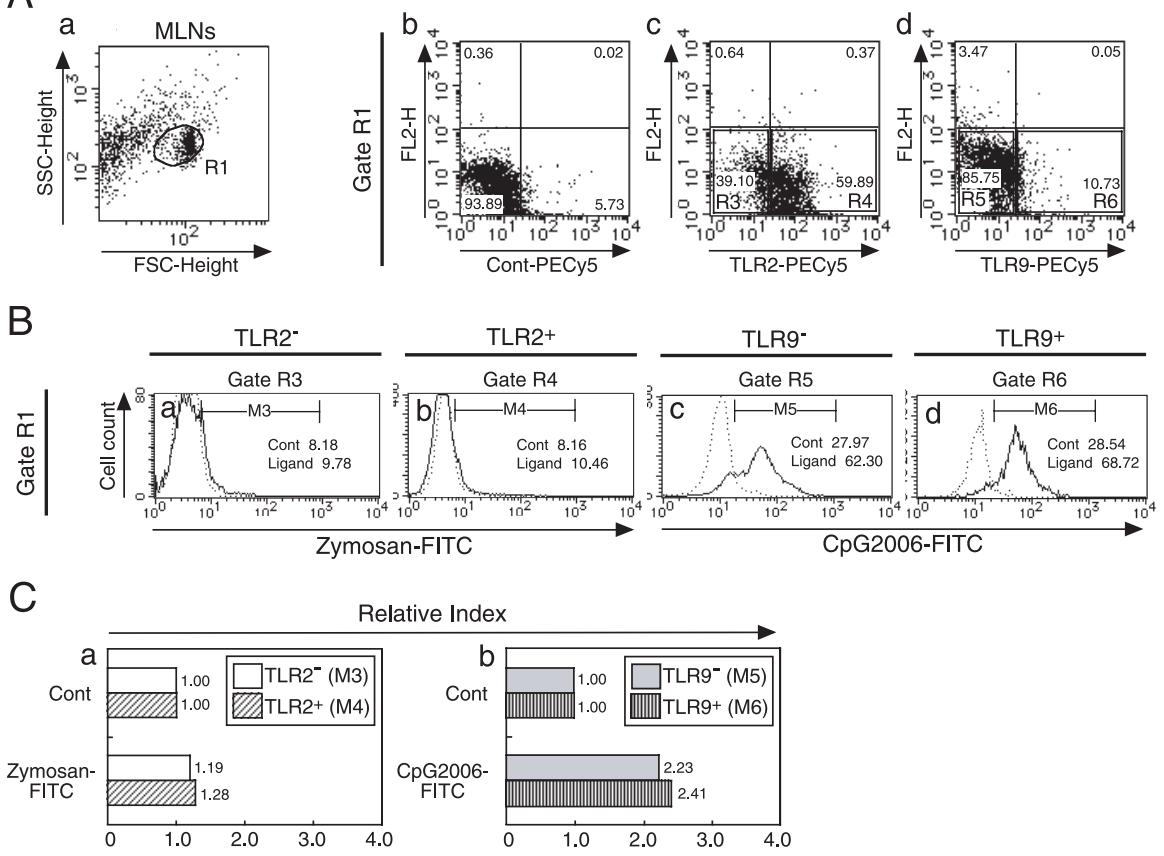

Figure 5. Flow cytometric analysis of the expression and ligand binding by TLR2 and TLR9 in newborn swine MLN. Isolated cells $\left(2 \times 10^{6}\right)$ were incubated with FITC-zymosan $(10 \mu \mathrm{g} / \mathrm{mL})$ or FITC-CpG2006 $(1 \mu \mathrm{M})$. After $1 \mathrm{~h}$, the cells were stained with anti-TLR2 or anti-TLR9 Ab and analyzed by flow cytometry. (A) Double immunofluorescence of the cell suspensions from newborn swine MLN using Ab specific for swine TLR2 (A-c; X-axis) or swine TLR9 (A-d; X-axis) or using normal rabbit IgG (A-b; X-axis). Dot plots of gate R1 (A-b, A-c, A-d) for newborn swine MLN (A-a) are shown. The data represent 50000 live cell events, with the percentages of cells shown in each quadrant. For the analysis of ligand binding, the dot plots were gated as R3-R6 in panels (A-c) and (A-d). (B) Ligand binding of FITC-zymosan (B-a, B-b) and FITC-CpG2006 (B-c, B-d) in each cell population. Flow cytometric results are presented as histograms corresponding to the cells in gates R3-R6 gates in (A-c) and (A-d). Dotted lines, unstimulated cells; solid line, cells stimulated with FITC-zymosan or FITC-CpG2006. The mean fluorescence intensity of FITCconjugated ligands bound to unstimulated or stimulated cells in gates M3-M6 is shown in each panel. (C) The results of histograms in (B) are expressed as the relative index compared to the estimated mean fluorescence intensity of FITC-conjugated ligands (FITC-zymosan, C-a; FITCCpG2006, C-d) compared with unstimulated cells in each gate. Similar results were obtained from at least nine different newborn swine.

The gate R1 population from MLN and ileal Pps contained TLR2 ${ }^{+}$cells (lower right quadrants of Figs. 5A-c and 6A-c) and $\mathrm{TLR}^{+}$cells (lower right quadrants of Figs. 5A-d and 6A-d). The gate R2 population from the ileal Pps contained cells positive for both TLR2 and cytok- eratin $18\left(\right.$ TLR$^{+} /$cytokeratin $18^{+}$; upper right quadrant of Fig. 6A-f) as well as cells positive for both TLR9 and cytokeratin 18 (TLR9 $^{+} /$cytokeratin $18^{+}$; upper right quadrant of Fig. 6A-g), strongly suggesting that TLR2- or TLR9-expressing $M$ cells exist in the FAE of ileal Pps. 
A
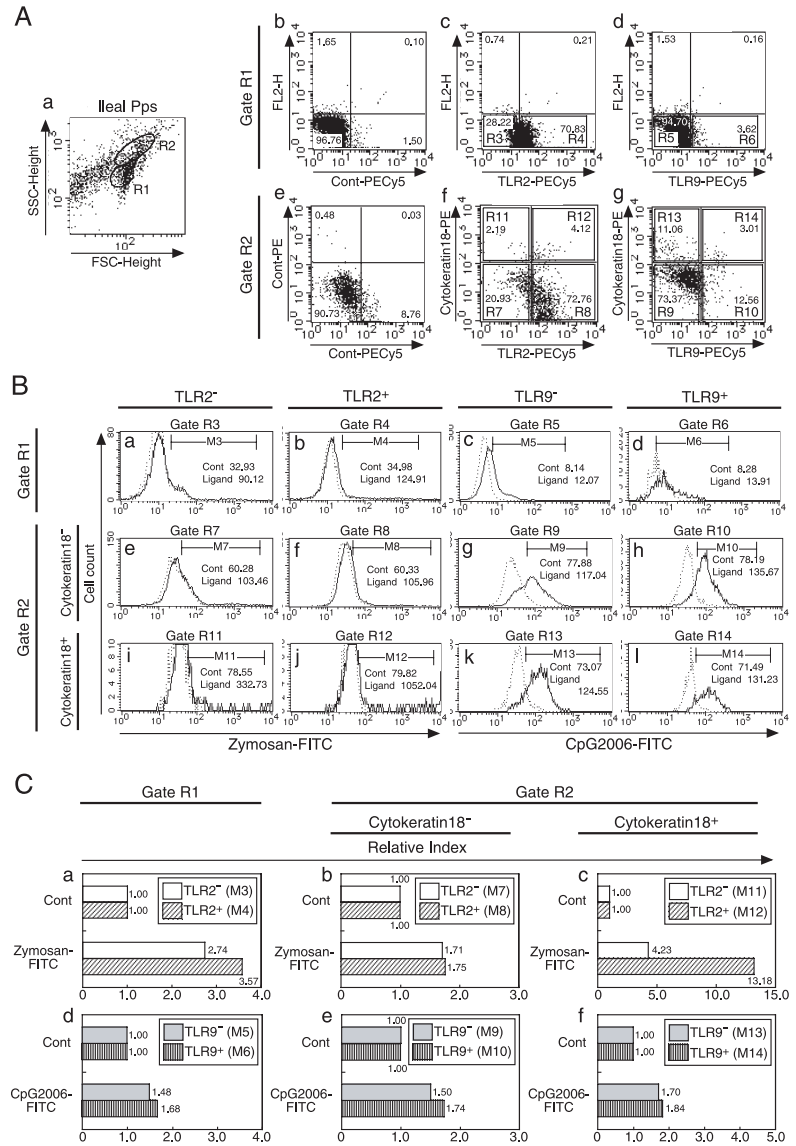

Figure 6. Flow cytometric analysis of TLR2 and TLR9 expression and ligand binding in newborn swine ileal Pps. Isolated cells $\left(2 \times 10^{6}\right.$ cells $)$ were incubated with FITC-zymosan $(10 \mu \mathrm{g} / \mathrm{mL})$ or FITC-CpG2006 $(1 \mu \mathrm{M})$. After $1 \mathrm{~h}$, the cells were stained with Abs to cytokeratin 18 and either swine TLR2 or TLR9. The cells were then analyzed by flow cytometry. (A) Double immunofluorescence of the cell suspensions from newborn swine ileal Pps using an Ab specific for swine TLR2 (A-c, A-f; X-axis), an Ab to swine TLR9 (A-d, A-g; X-axis), or normal rabbit IgG (A-b, A-e; X-axis) along with either a $\mathrm{mAb}$ to cytokeratin 18 (A-f, A-g; Y-axis) or normal mouse $\operatorname{IgG}$ (A-e; Y-axis). Dot plots for gates R1 (A-b, A-c, A-d) and R2 (A-e, A-f, A-g) of newborn swine ileal Pps (A-a) are shown. The data represent 50000 live cell events, with the percentages of cells shown in each quadrant. For ligand binding analysis, the dot plots were gated as R3-R14 in panels (A-c, A-d, A-f, A-g). (B) Binding of FITC-zymosan (B-a, B-b, B-e, B-f, B-i, B-j) and FITC-CpG2006 (B-c, B-d, B-g, B-h, B-k, B-l) to each cell population. Flow cytometric results are presented as histograms corresponding to the cells in gates R3-R14 in (A-c, A-d, A-f, A-g). Dotted lines, unstimulated cells; solid line, cells stimulated with FITC-zymosan or FITC-CpG2006. The mean fluorescence intensity of FITC-conjugated ligands on unstimulated or stimulated cells in gates M3-M14 is shown in each panel. (C) The results of the histograms in (B) are expressed as the relative index compared to the estimated mean fluorescence intensity of FITC-conjugated ligands (FITC-zymosan, C-a, C-b, C-c; FITC-CpG2006, C-d, C-e, C-f) and compared with unstimulated cells in each gate. Similar results were obtained from at least nine different newborn swine. 
The gate R2 population also included $\mathrm{TLR}^{+}{ }^{+}$or TLR9 ${ }^{+}$cells that were negative for cytokeratin 18 (TLR2 $^{+} /$cytokeratin $18^{-}$ and $\mathrm{TLR}^{+} /$cytokeratin $18^{-}$, respectively; lower right quadrants of Figs. 6A-f and 6A-g), suggesting the presence of TLR2or TLR9-expressing enterocytes.

Next, we divided the cells from MLN and ileal Pps into distinct cell populations based on TLR and cytokeratin $18 \mathrm{ex}-$ pression levels (gates R3-6 in Figs. 5A-c and 5A-d and gates R3-14 in Figs. 6A-c, 6A-d, 6A-f, and 6A-g). Both TLR2 ${ }^{+}$and TLR2 ${ }^{-}$cells of MLN and ileal Pps recognized FITC-labeled zymosan (Figs. 5B-a, 5B-b and 6B-a, 6B-b, 6B-e, 6B-f, 6B-i, $6 B-j)$. Interestingly, the mean fluorescence intensities for zymosan binding were considerably higher for $\mathrm{TLR}^{+}$than $\mathrm{TLR}^{-}$ cells in gate R1 as well as for cytokeratin $18^{+}$cells from ileal Pps (Figs. 6C-a, 6C-c). In particular, $\mathrm{TLR}^{+} /$cytokeratin $18^{+}$cells bound approximately 3-fold more FITCzymosan than TLR2 ${ }^{-} /$cytokeratin $18^{+}$cells (Figs. 6B-i, 6B-j and 6C-c). On the contrary, the TLR2 expression levels had a slight influence on the binding of FITCzymosan to gate R1 cells from MLN and the cytokeratin $18^{-}$cells from ileal Pps (Fig. 5C-a and Fig. 6C-b).

Significant binding of FITC-labeled CpG2006 was detected not only on TLR9 ${ }^{+}$ cells but also on TLR9- cells in MLN and ileal Pps (Figs. 5B-c, 5B-d and Figs. 6B-c, 6B-d, 6B-g, 6B-h, 6B-k, 6B-1), although the level of binding was slightly higher for $\mathrm{TLR}^{+}$than $\mathrm{TLR}^{-}$cells in all cell populations from MLN and ileal Pps.

\subsection{Augmentation of mitogenic activity by zymosan, CpG2006, and LAB}

Our immunohistochemical and flow cytometric analyses showed that TLR2or TLR9-expressing cells from newborn swine MLN and ileal Pps preferentially bound their ligands compared to cells that do not express the TLR. Therefore, we next investigated the immune responses of newborn swine MLN and ileal Pps to zymosan, CpG2006, and LAB, to determine whether TLR2- or TLR9-expressing cells contribute to immune system function immediately after birth.

We first examined the effect of zymosan, CpG2006, and LAB on mitogenic activity in newborn swine MLN and ileal Pps cells. As shown in Fig. 7A, zymosan and CpG2006 strongly induced mitogenesis in ileal Pps (stimulation index $[\mathrm{SI}]=4.7$ and 2.2 , respectively). Mitogenesis was also induced by $L$. gasseri $\mathrm{JCM} 1131^{\mathrm{T}}(\mathrm{SI}=4.1)$ and $L$. bulgaricus NIAI B6. In addition, CpG2006 had significant mitogenic activity in newborn swine MLN cells (Fig. 7B; SI = 3.9). Although the mitogenicity of zymosan, L. gasseri JCM $1131^{\mathrm{T}}$, and $L$. bulgaricus NIAI B6 was lower in cells from MLN than in cells from ileal Pps, the effects in MLN cells were statistically significant (Fig. 7B; SI = $1.4,1.5$, and 2.0 , respectively).

\subsection{Induction of cytokine gene transcription by zymosan, CpG2006, and LAB in newborn swine MLN and ileal Pps}

To investigate whether zymosan, CpG2006, and LAB stimulate other immune responses besides cell proliferation, we used real-time quantitative PCR to examine their abilities to induce cytokine gene expression in MLN and ileal Pps (Fig. 8). Zymosan induced significant increases in the levels of IFN- $\gamma$, IL-12p35, IL-6, IL-10 and TGF- $\beta$ gene transcripts in cells from ileal Pps (Fig. 8A). Although zymosan did not activate IFN- $\gamma$, IL-12p35, and IL-10 expression in MLN cells, it did activate the expression of the IL-6 and TGF- $\beta$ genes (Fig. 8B). CpG2006 greatly induced the expression of all of the tested cytokine genes in MLN cells. 

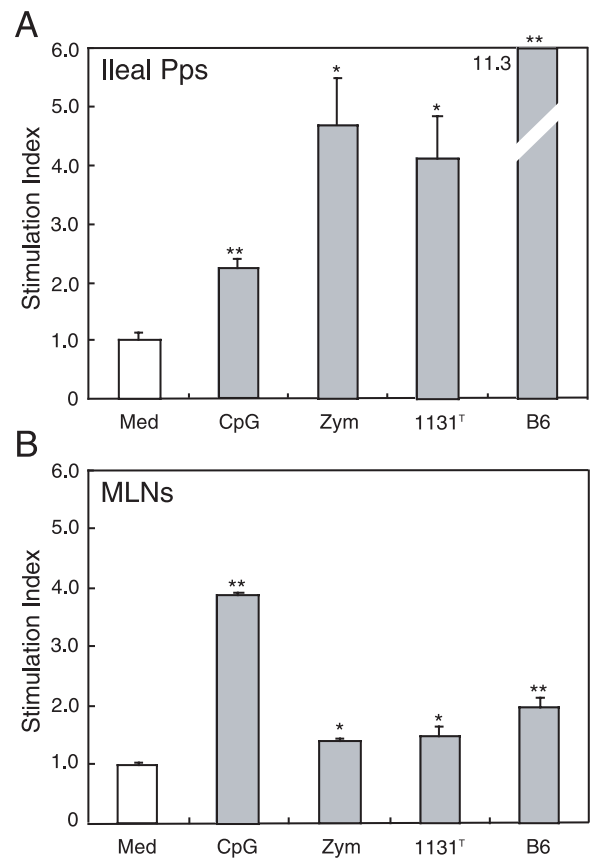

\subsection{Microbial stimulation increases expression of TLR2 and TLR9 in newborn swine GALT}

The postnatal period is important in the development of the system that recognizes intestinal microorganisms. Therefore, we then analyzed the effects of various microbes on the expression of TLR2 and TLR9 in GALT immediately after birth. In immature ileal Pps, CpG2006, zymosan, L. bulgaricus NIAI B6, and L. gasseri JCM $1131^{\mathrm{T}}$ significantly enhanced the expression of TLR2 and TLR9 (Figs. 9A,

Figure 7. Mitogenic activity of CpG2006 and zymosan towards newborn swine ileal Pps and MLN. Cells $\left(2 \times 10^{5} /\right.$ well $)$ isolated from ileal Pps (A) or MLN (B) were cultured in 96-well plates for $48 \mathrm{~h}$. Mitogenic activity was examined in the presence of $10 \mu \mathrm{M}$ CpG2006 (CpG), $10 \mu \mathrm{g} / \mathrm{mL}$ zymosan (Zym), $100 \mu \mathrm{g} / \mathrm{mL}$ L. gasseri JCM1 $131^{\mathrm{T}}\left(1131^{\mathrm{T}}\right)$, or $100 \mu \mathrm{g} / \mathrm{mL} L$. bulgaricus NIAI B6 (B6). Sixteen h before harvest, the cells were pulse-labeled with $9.25 \mathrm{kBq}$ (methyl- ${ }^{3} \mathrm{H}$ )-uridine. Cell proliferation was determined by measuring ${ }^{3} \mathrm{H}$ incorporation. Values represent means, and error bars indicate the standard deviations. Each experiment was repeated nine times. ${ }^{* *} P<0.01,{ }^{*} P<0.05$ vs. cells cultured in the absence of stimulants.

Of these genes, IFN- $\gamma$ gene expression was increased the most. CpG2006 also stimulated the expression of IL-6 and TGF- $\beta$ but not other cytokine genes in cells from ileal Pps (Fig. 8A). In the ileal Pps, L. gasseri JCM1131 ${ }^{\mathrm{T}}$ strongly stimulated IFN- $\gamma$, IL-12p35, IL-6, IL-10, and TGF- $\beta$ gene expression. L. bulgaricus 9B). In addition, CpG2006, zymosan, $L$. bulgaricus NIAI B6 and $L$. gasseri JCM $1131^{\mathrm{T}}$ increased the expression of TLR2 mRNA in MLN (Fig. 9B). Also, the expression of TLR9 was significantly increased by CpG2006, zymosan, L. bulgaricus NIAI B6, and L. gasseri JCM1131 ${ }^{\mathrm{T}}$ (Fig. 9B).

\section{DISCUSSION}

In the present study, we demonstrated that, within intestinal tissues and GALT of newborn swine, TLR2 and TLR9 are strongly expressed in the ileal Pps and MLN. Similarly, our previous studies found that TLR2 and TLR9 are preferentially expressed in ileal Pps and MLN among intestinal tissues and GALT of adult swine [40, 48]. However, the expression levels of both TLR in GALT are different between newborn and adult swine as compared with other lymphoid tissues. In newborn swine, expression of 


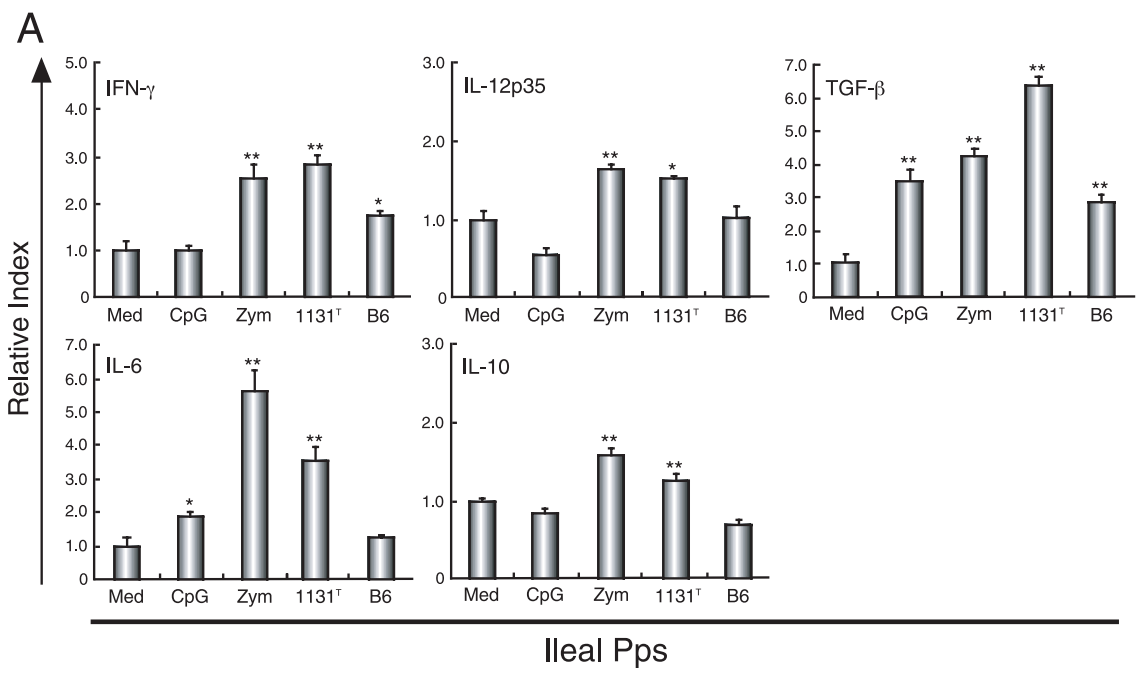

B

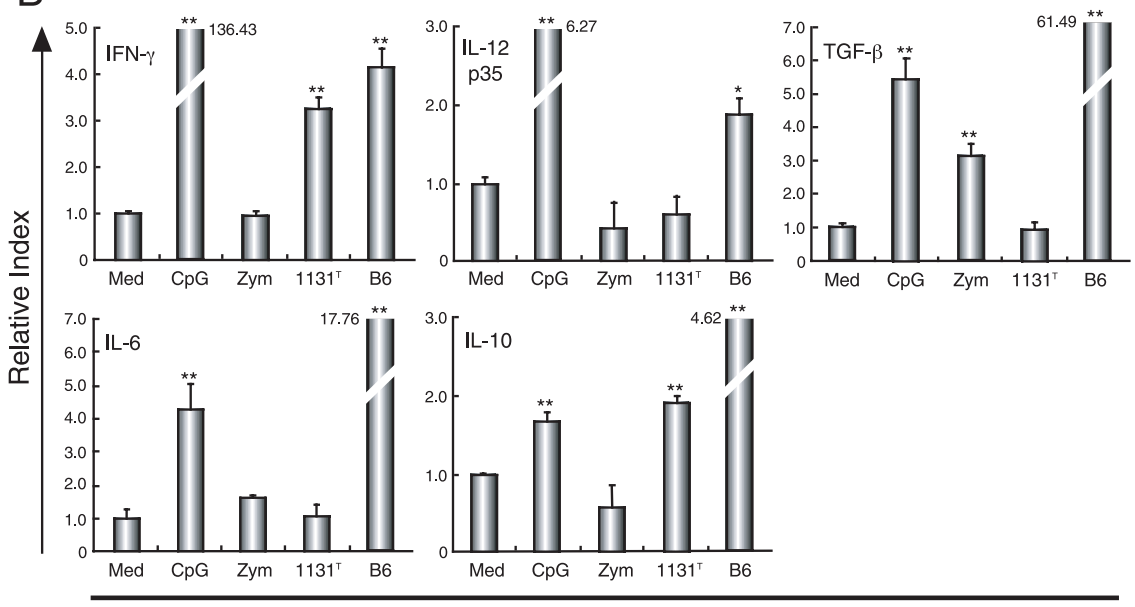

MLNs

Figure 8. Analysis of cytokine mRNA expression in swine newborn ileal Pps and MLN. Cells $\left(1 \times 10^{6}\right)$ from ileal Pps (A) and MLN (B) were cultured in the absence (medium control) or presence of CpG2006 (CpG; $10 \mu \mathrm{M})$, zymosan $(\mathrm{Zym} ; 10 \mu \mathrm{g} / \mathrm{mL})$, L. gasseri JCM1131 $\left(1131^{\mathrm{T}}\right.$; $100 \mu \mathrm{g} / \mathrm{mL}$ ), or L. bulgaricus NIAI B6 (B6; $100 \mu \mathrm{g} / \mathrm{mL}$ ). Expression of IFN- $\gamma$, IL-12p35, IL-6, IL-10, and TGF- $\beta$ mRNA were determined by real-time PCR. The results are expressed as the relative mRNA index, which was calculated as the mRNA index (estimated cytokine mRNA copy number/estimated $\beta$-actin mRNA copy number) for stimulated cells divided by the mRNA index for unstimulated cells. Columns represent the mean relative index, and error bars indicate the standard errors. Each experiment was repeated five times. ${ }^{* *} p<0.01$ and $^{*} p<0.05$ vs. cells cultured in the absence of stimulants. 

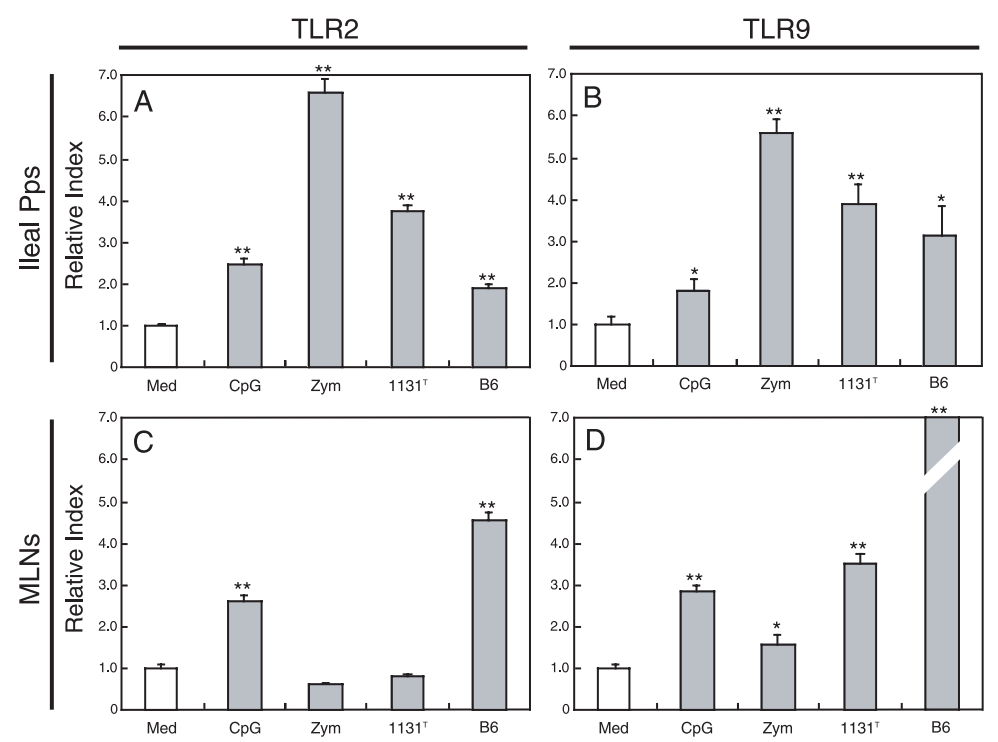

Figure 9. Expression of TLR2 and TLR9 is induced by various stimuli in swine newborn ileal Pps and MLN immediately after birth. Cells $\left(1 \times 10^{6}\right.$ cells $)$ from ileal Pps $(\mathbf{A}, \mathbf{B})$ and MLN $(\mathbf{C}, \mathbf{D})$ were cultured in the absence (medium control) or presence of CpG2006 (CpG; $10 \mu \mathrm{M})$, zymosan (Zym; $10 \mu \mathrm{g} / \mathrm{mL})$, L. gasseri JCM1131 ${ }^{\mathrm{T}}\left(1131^{\mathrm{T}} ; 100 \mu \mathrm{g} / \mathrm{mL}\right)$, or L. bulgaricus NIAI B6 (B6; $\left.100 \mu \mathrm{g} / \mathrm{mL}\right)$. Expression of TLR2 (A, C) and TLR9 (B, D) mRNA were determined by real-time PCR. The results are expressed as the relative mRNA index, which was calculated as described in Fig. 8. Columns represent the mean relative index, and error bars indicate the standard errors. Each experiment was repeated five times. ${ }^{* *} p<0.01$ and ${ }^{*} p<0.05$ vs. cells cultured in the absence of stimulants.

TLR2 was around 1.5 fold higher in ileal Pps but lower in MLN as compared with spleen. While, in ileal Pps and MLN of adult swine, expression of TLR2 in both tissues is more than 8-fold higher than in other lymphoid tissues, including the spleen and thymus [48]. In the analysis of TLR9 expression, similar results were obtained from the present and previous studies. Considerable expression of TLR9 was observed in ileal Pps and MLN of adult swine, which showed about 3-fold higher expression than spleen and thymus [40]. However, MLN showed moderately higher levels of TLR9 (1.33-fold) than spleen in newborn swine. Thus, the expression levels of these two TLR were higher in GALT of adults than in that of newborns when their expressions were cal- culated as the relative index compared to spleen. Several studies using germ-free animals have demonstrated the importance of normal microflora in the gut for the normal development of the mucosal immune system during postnatal periods $[33,36]$. In contrast to peripheral secondary lymphoid organs such as the spleen, which obtain antigens from afferent lymphatics or blood, GALT directly collect antigens across the specialized FAE that separate the outside from the inside [32]. The different expression levels of TLR in newborn and adult swine GALT provide the idea that the intestinal microflora directly promotes the expression of TLR2 and TLR9 in the ileal Pps and MLN during postnatal development of the GALT, resulting in the high expression of TLR2 and TLR9 in adult 
GALT. Indeed, the present study showed that microbes such as LAB and microbial components significantly increased the expression of TLR2 and TLR9 in newborn ileal Pps and MLN, suggesting that stimulation with intestinal microbes is critical for regulating the expression of TLR2 and TLR9 immediately after birth and, thus, the development of a system for recognizing intestinal microorganisms.

Immunohistochemical analysis of MLN in newborn swine revealed that TLR2 ${ }^{+}$ cells were located in medullary cords and lymphoid follicles of MLN, whereas TLR9 $^{+}$cells were present in and around the lymphoid follicles of MLN. In the ileal Pps, TLR2 ${ }^{+}$cells were frequently present in the lymphoid follicles, whereas $\mathrm{TLR}^{+}$cells were located immediately around the lymphoid follicles. These follicles have been reported to consist of $\mathrm{T}$ cells, B cells, lymphoblasts, follicular dendritic cells, and macrophages [29]. In addition, both $\mathrm{TLR}^{+}$cells and TLR9 ${ }^{+}$ cells were found in the interfollicular areas. These interfollicular areas have been reported to include $\mathrm{T}$ cells, interdigitating dendritic cells, and macrophages [29]. Therefore, TLR2 ${ }^{+}$or TLR9 ${ }^{+}$cells in the interfollicular area may play a crucial role in the activation of the immune system in presuckling newborns.

Flow cytometric analysis also showed that MLN and ileal Pps contained TLR2 ${ }^{+}$ cells and TLR9 $^{+}$cells. In our previous studies, gate R1 contained leukocytes and lymphocytes such as dendritic cells, macrophages, T cells, and B cells, whereas Gate R2 contained epithelial cells such as enterocytes and $M$ cells [40, 48]. The present results revealed that more zymosan was bound by TLR2 $^{+}$immune cells than by TLR2- immune cells from ileal Pps, whereas cells from MLN showed a smaller difference in zymosan binding. This difference might be due to the distinct subsets of immune cells and specific TLR2 expression levels in ileal Pps and MLN. This is supported by recent reports that phenotypic differences of lymphoid cell populations appear to depend on swine GALT, including MLN and ileal Pps [43]. Our current study also revealed that the level of TLR2 expression was higher in ileal Pps than in MLN. In TLR2 ${ }^{-}$cells, there may be a low level of zymosan binding by other receptors, such as TLR6 [50] and dectin-1 [5]. Moreover, the present results indicate that, even in immature GALT, TLR2 can recognize zymosan and may participate in various immune responses.

Our studies further indicate that both TLR9 $^{+}$and TLR9 $^{-}$cells from MLN and ileal Pps strongly bind the DNA motif CpG2006. Recently, Klinman et al. reported that the CpG DNA motif associates with the cell surface and is transported to the cytoplasm by the nonspecific endocytosis within $10 \mathrm{~min}$ [27]. In addition, TLR9 is preferentially expressed not on the cell surface but rather in the intracellular regions [27]. These findings suggest that CpG2006 is randomly taken up into the cytoplasm regardless of the extent of TLR9 expression and then recognized by intracellular TLR9. Indeed, we found that TLR9 ${ }^{+}$cells bind slightly more CpG2006 than TLR9- cells. This binding of CpG2006 may be mediated by intracellular TLR9.

The majority of studies conducted so far on the neonatal immune system have used cord blood mononuclear cells rather than cells derived from the GALT. Recently, Karlsson et al. reported that there is a relationship between cytokine production by neonatal immune cells and bacteria in normal gastrointestinal flora [21]. The neonatal immune cells separated from umbilical cord blood produced considerably higher levels of IL-12 and TNF- $\alpha$ upon stimulation with gram-positive bacteria than with gram-negative bacteria, although these two types of bacteria induced similar levels of IL-6 and IL-10 production. Other researchers have recently 
reported that cord blood cells expressing TLR2 produce IL-1 $\beta$, IL-6, IL-8, IL-10, and TNF- $\alpha$ after stimulation with bacterial cell wall components [1]. Study of immune responses induced by intestinal bacteria, however, should be directly conducted on cells from the GALT because cord blood cells do not accurately represent GALT cells.

In the present study, zymosan, CpG2006, L. bulgaricus NIAI B6, and L. gasseri $\mathrm{JCM} 1131^{\mathrm{T}}$ strongly induced mitogenesis in newborn swine ileal Pps and MLN. Recently, Frasnelli et al. [12] reported that TLR2-deficient mice show a significant decrease in lymph node cell proliferation and a lower IgG Ab in response to zymosan, indicating that TLR2 signaling has an important role in the development of acquired immune responses to zymosan. Corresponding data on the importance of TLR9 in acquired immunity to CpG-DNA have also been reported [41]. In addition, L. bulgaricus NIAI $\mathrm{B} 6$ and $L$. gasseri $\mathrm{JCM} 1131^{\mathrm{T}}$ are specifically recognized by cells transfected with TLR2 [47], and their genomic DNA strongly activates the immune system via TLR9 [24, 25, 37-39, 41]. Together with our current findings that many cells from MLN and ileal Pps express TLR2 and TLR9, these results suggest that, even in immature MLN and ileal Pps, zymosan and CpG2006 induce a strong immune response via TLR2 and TLR9, respectively. Furthermore, LAB, which have many ligands for TLR2 and TLR9, also activate cells from MLN and ileal Pps, resulting in modulation of the intestinal immune response even in newborn swine.

Analysis of cytokine expression revealed that treatment of ileal Pps cells with zymosan up-regulates the expression of multiple cytokines, including Th1 (IFN- $\gamma$ and IL12p35), Th2 (IL-6), and T regulatory (Treg) cytokines (IL-10 and TGF- $\beta$ ). In MLN cells, zymosan did not activate the expression of the IFN- $\gamma$, IL-12p35, or
IL-10 genes, but it significantly enhanced IL- 6 and TGF- $\beta$ gene expression. Again, the differences in cytokine expression between ileal Pps and MLN may be influenced by the distinct subset of immune cells and the relative expression levels of TLR2 between these two tissues.

Because the GALT is immature immediately after birth due to a lack of prior encounters with PAMP, it rarely develops characteristics of an immune regulatory system such as immune tolerance [2]. Immediately after birth, the ability of the immature GALT to induce active responses to foreign antigens is thought to develop in parallel with the ability to control and regulate such responses [2]. Our current results indicate that zymosan is recognized by TLR 2 in newborn GALT, which then activates immune responses via induction of multiple cytokines (Th1 and Th2). In addition, it appears that zymosan simultaneously induces suppressive $\mathrm{T}$ cell responses and immune tolerance to intestinal antigens via Treg cytokines such as IL-10 and TGF- $\beta$ [11].

Our studies also showed that $\mathrm{CpG} 2006$ strongly induces IFN- $\gamma$, IL-12p35, IL-6, IL- 10 , and TGF- $\beta$ gene expression in MLN cells. In agreement with our current results, others have reported that, in some cases, TLR9 signaling participates in the production of IFN- $\gamma$, IL-12p35, IL-6, IL-10, and TGF- $\beta[6,8,26]$. In the ileal Pps, CpG2006 also induced the expression of the IL-6 and TGF- $\beta$ genes but not other cytokine genes. Newborn swine ileal Pps may have lower cytokine production than MLN because they express less TLR9. Furthermore, because only plasmacytoid dendritic and B cells express TLR9 in human and swine immune cells $[14,16]$, the specific proportions of these two cell types in ileal Pps and MLN may result in different extents of cytokine production.

In addition, we found that, in the ileal Pps, L. gasseri JCM1131 ${ }^{\mathrm{T}}$ strongly stimulated IFN- $\gamma$, IL12p35, IL-6, IL-10, and 
TGF- $\beta$ gene expression and that L. bulgaricus NIAI B6 stimulated IFN- $\gamma$ and TGF- $\beta$ gene expression. However, in MLN, L. bulgaricus NIAI B6 significantly induced all cytokine genes, whereas $L$. gasseri JCM $1131^{\mathrm{T}}$ activated only IFN- $\gamma$ and IL-10 gene expression. In summary, L. gasseri JCM1131 ${ }^{\mathrm{T}}$, which was isolated from human intestine, strongly induced Th1 and Treg cytokines in newborn ileal Pps, tissues that have direct access to contents of the lumen. In addition, L. bulgaricus NIAI B6, a starter for yogurt production, significantly activated immune responses in MLN from the afferent lymphatics of the ileal Pps, where dendritic cells transport intestinal bacteria [28]. Both LAB strains, however, strongly activated IFN- $\gamma$ expression in newborn ileal Pps and MLN. This suggests that the different patterns of cytokine production induced by the two LAB strains have different effects. This may be due to the different structure and quantity of bacterial components (e.g., genomic DNA and cell wall components) in the two strains. Our current results combined with the widely accepted hygiene hypothesis suggest that TLR2 and TLR9 are expressed in newborn swine GALT where they recognize intestinal microorganisms immediately after birth and mediate activation of immune responses that maintain the Th1/Th2 balance necessary for innate immunity.

$\mathrm{M}$ cells play a unique role in delivering antigenic components and microorganisms across epithelial barriers to initiate immune responses or tolerance by lymphoid cells lying within and beneath the epithelium [34]. We previously reported that TLR2 and TLR9 are strongly expressed in the GALT not only by immune cells, such as dendritic and B cells, but also by cells in the FAE, including pocket-like $M$ cells $[40,48]$. In the present study, in agreement with the results of Kido et al. [22], the $\mathrm{M}$ cells were columnar in shape, similar to neighboring enterocytes, and did not show a pocket-like morphology. Double immunohistochemical staining and flow cytometric analysis confirmed that columnar $M$ cells in newborn swine express TLR2 and TLR9. Moreover, TLR2 was preferentially expressed on the apical side of the membrane. These findings agree with the well-established subcellular expression of TLR2 in innate immune cells and epithelial cell lines [7, 49]. For instance, TLR2 is mostly distributed on the cell surface and is specifically recruited within 5 min by zymosan-incorporating macrophage phagosomes [49]. TLR2 was also shown to be expressed at the apical membrane [7] of T84 human intestinal epithelial cells. Interestingly, $\mathrm{TLR}^{+} /$cytokeratin $18^{+}$cells bound more zymosan than TLR2 ${ }^{-} /$cytokeratin $18^{+}$cells or neighboring enterocytes. These results suggest that columnar $\mathrm{M}$ cells recognize intestinal microflora via TLR2 mostly on the apical side of the membrane and that intracellular recognition of bacterial DNA is mediated by TLR9 in the cytoplasm. Thus, TLR 2 and TLR9 are expected to mediate immune activation of not only TLR $2^{+}$ or TLR9 $^{+}$lymphoid cells located beneath the FAE, but also $\mathrm{M}$ cells. Furthermore, the potential function of TLR2 as a pattern recognition receptor along with its cellular distribution suggest that TLR2 plays an important role in ligand-specific transcytosis and transport in newborn swine $\mathrm{M}$ cells. This possibility is further supported by the well-established relationship between TLR 2 signaling and transcytosis.

Recently, TLR2 ligands have been found to specifically promote bacterial phagocytosis in both murine and human macrophage cells through the IL-1 receptor-associated kinase 4 and the p38dependent induction of a phagocytic gene program [10]. Moreover, activation of the TLR2 and TLR4 signaling pathways by gram-negative and -positive bacteria regulates multiple phases of phagocytosis in macrophages, including internalization 
and phagosome maturation [3]. Furthermore, phagocytosis of green fluorescent protein-expressing bacteria is impaired in TLR2 ${ }^{-} /$TLR $^{-}$macrophages [3], suggesting that TLR2 plays a crucial role in the transcytosis of entire microorganisms. Although the precise function and characteristics of columnar $\mathrm{M}$ cells remain unknown, our current results should provide some insight into the immune responses that they mediate. More detailed studies are needed to resolve the immunological function of TLR2 and TLR9 in M cells.

The present results are valuable for determining the role of TLR2 and TLR9 in newborn swine as a model of the newborn human immune system. The functional expression of TLR2 and TLR9, even in immature ileal Pps and MLN, strongly suggests that these two receptors can mediate immune responses of the immature GALT to commensal microorganisms, such as immunobiotic LAB, and their cell components. TLR2 ${ }^{+}$or TLR9 $^{+}$ $\mathrm{M}$ cells, in particular, may play important roles in the recognition and immune response to immunobiotic LAB. Understanding the functional role of TLR2 and TLR9 in the immature GALT should also help in the development of oral vaccines and physiologically functional foods that specifically target immune responses in the GALT.

\section{ACKNOWLEDGEMENTS}

This study was partly supported by a Grant-in-Aid for Scientific Research (B)(2) (No. 15380183, 18380158) from the Japan Society for the Promotion of Science to $\mathrm{H}$. Kitazawa and by the Secure and Healthy Animal Production project from the Ministry of Agriculture, Forestry and Fisheries of Japan to H. Aso and H. Kitazawa. M. Tohno is supported by JSPS research fellow (Research Fellowships for Young Scientists Program, No. 18005121).

\section{REFERENCES}

[1] Amoudruz P., Holmlund U., Malmstrom V., Trollmo C., Bremme K., Scheynius A., Sverremark-Ekstrom E., Neonatal immune responses to microbial stimuli: is there an influence of maternal allergy? J. Allergy Clin. Immunol. 115 (2005) 1304-1310.

[2] Bailey M., Haverson K., Inman C., Harris C., Jones P., Corfield G., Miller B., Stokes C., The development of the mucosal immune system pre- and post-weaning: balancing regulatory and effector function, Proc. Nutr. Soc. 64 (2005) 451-457.

[3] Blander J.M., Medzhitov R., Regulation of phagosome maturation by signals from toll-like receptors, Science 304 (2004) 1014-1018.

[4] Bowman L.M., Holt P.G., Selective enhancement of systemic Th1 immunity in immunologically immature rats with an orally administered bacterial extract, Infect. Immun. 69 (2001) 3719-3727.

[5] Brown G.D., Herre J., Williams D.L., Willment J.A., Marshall A.S., Gordon S., Dectin-1 mediates the biological effects of beta-glucans, J. Exp. Med. 197 (2003) 1119-1124.

[6] Brummel R., Lenert P., Activation of marginal zone B cells from lupus mice with type A(D) CpG-oligodeoxynucleotides, J. Immunol. 174 (2005) 2429-2434.

[7] Cario E., Brown D., McKee M., LynchDevaney K., Gerken G., Podolsky D.K., Commensal-associated molecular patterns induce selective toll-like receptor-trafficking from apical membrane to cytoplasmic compartments in polarized intestinal epithelium, Am. J. Pathol. 160 (2002) 165-173.

[8] Chow E.K., O'connell R.M., Schilling S., Wang X.F., Fu X.Y., Cheng G., TLR agonists regulate PDGF-B production and cell proliferation through TGF-beta/type I IFN crosstalk, EMBO J. 24 (2005) 4071-4081.

[9] Clancy R., Immunobiotics and the probiotic evolution, FEMS Immunol. Med. Microbiol. 38 (2003) 9-12.

[10] Doyle S.E., O'Connell R.M., Miranda G.A., Vaidya S.A., Chow E.K., Liu P.T., Suzuki S., Suzuki N., Modlin R.L., Yeh W.C., Lane T.F., Cheng G., Toll-like receptors induce a phagocytic gene program through p38, J. Exp. Med. 199 (2004) 81-90.

[11] Faria A.M., Weiner H.L., Oral tolerance, Immunol. Rev. 206 (2005) 232-259. 
[12] Frasnelli M.E., Tarussio D., Chobaz-Peclat V., Busso N., So A., TLR2 modulates inflammation in zymosan-induced arthritis in mice, Arthritis Res. Ther. 7 (2005) R370-R379.

[13] Gebert A., Rothkotter H.J., Pabst R., Cytokeratin 18 is an M-cell marker in porcine Peyer's patches, Cell Tissue Res. 276 (1994) 213-221.

[14] Guzylack-Piriou L., Balmelli C., McCullough K.C., Summerfield A., Type-A $\mathrm{CpG}$ oligonucleotides activate exclusively porcine natural interferon-producing cells to secrete interferon-alpha, tumour necrosis factor-alpha and interleukin-12, Immunology 112 (2004) 28-37.

[15] Hartmann G., Weeratna R.D., Ballas Z.K., Payette P., Blackwell S., Suparto I., Rasmussen W.L., Waldschmidt M., Sajuthi D., Purcell R.H., Davis H.L., Krieg A.M., Delineation of a $\mathrm{CpG}$ phosphorothioate oligodeoxynucleotide for activating primate immune responses in vitro and in vivo, $\mathrm{J}$. Immunol. 164 (2000) 1617-1624.

[16] Hochrein H., Wagner H., Of men, mice and pigs: looking at their plasmacytoid dendritic cells, Immunology 112 (2004) 26-27.

[17] Iliev I.D., Kitazawa H., Shimosato T., Katoh S., Morita H., He F., Hosoda M., Saito T., Strong immunostimulation in murine immune cells by Lactobacillus rhamnosus GG DNA containing novel oligodeoxynucleotide pattern, Cell. Microbiol. 7 (2005) 403-414.

[18] Kalliomaki M., Kirjavainen P., Eerola E., Kero P., Salminen S., Isolauri E., Distinct patterns of neonatal gut microflora in infants in whom atopy was and was not developing, J. Allergy Clin. Immunol. 107 (2001) 129-134.

[19] Kalliomaki M., Salminen S., Arvilommi H., Kero P., Koskinen P., Isolauri E., Probiotics in primary prevention of atopic disease: a randomised placebo-controlled trial, Lancet 357 (2001) 1076-1079.

[20] Kamstrup S., Verthelyi D., Klinman D.M., Response of porcine peripheral blood mononuclear cells to $\mathrm{CpG}$-containing oligodeoxynucleotides, Vet. Microbiol. 78 (2001) 353-362.

[21] Karlsson H., Hessle C., Rudin A., Innate immune responses of human neonatal cells to bacteria from the normal gastrointestinal flora, Infect. Immun. 70 (2002) 6688-6696.

[22] Kido T., Ohwada S., Watanabe K., Aso H., Yamaguchi T., Differential characteristics of microfold cells on the dome epithelium of porcine ileum, Anim. Sci. J. 74 (2003) 375-382.
[23] Kitazawa H., Harata T., Uemura J., Saito T., Kaneko T., Itoh T., Phosphate group requirement for mitogenic activation of lymphocytes by an extracellular phosphopolysaccharide from Lactobacillus delbrueckii ssp. Bulgaricus, Int. J. Food Microbiol. 40 (1998) 169-175.

[24] Kitazawa H., Ueha S., Itoh S., Watanabe H., Konno K., Kawai Y., Saito T., Itoh T., Yamaguchi T., AT oligonucleotides inducing B lymphocyte activation exist in probiotic Lactobacillus gasseri, Int. J. Food Microbiol. 65 (2001) 149-162.

[25] Kitazawa H., Watanabe H., Shimosato T., Kawai Y., Itoh T., Saito T., Immunostimulatory oligonucleotide, CpG-like motif exists in Lactobacillus delbrueckii ssp. bulgaricus NIAI B6, Int. J. Food Microbiol. 85 (2003) 11-21.

[26] Klinman D.M., Yi A.K., Beaucage S.L., Conover J., Krieg A.M., CpG motifs present in bacteria DNA rapidly induce lymphocytes to secrete interleukin 6, interleukin 12, and interferon gamma, Proc. Natl. Acad. Sci. USA 93 (1996) 2879-2883.

[27] Klinman D.M., Takeshita F., Gursel I., Leifer C., Ishii K.J., Verthelyi D., Gursel M., CpG DNA: recognition by and activation of monocytes, Microbes Infect. 4 (2002) 897-901.

[28] Macpherson A.J., Uhr T., Induction of protective IgA by intestinal dendritic cells carrying commensal bacteria, Science 303 (2004) $1662-1665$.

[29] Makala L.H., Kamada T., Nishikawa Y., Nagasawa H., Igarashi I., Fujisaki K., Suzuki N., Mikami T., Haverson K., Bailey M., Stokes C.R., Bland P.W., Ontogeny of pig discrete Peyer's patches: distribution and morphometric analysis, Pathobiology 68 (2000) 275-282.

[30] Medzhitov R., Janeway C. Jr., Innate immune recognition: mechanisms and pathways, Immunol. Rev. 173 (2000) 89-97.

[31] Neurath M.F., Finotto S., Glimcher L.H., The role of Th1/Th2 polarization in mucosal immunity, Nat. Med. 8 (2002) 567-573.

[32] Neutra M.R., Mantis N.J., Kraehenbuhl J.P., Collaboration of epithelial cells with organized mucosal lymphoid tissues, Nat. Immunol. 2 (2001) 1004-1009.

[33] Pollard M., Sharon N., Responses of the Peyer's Patches in Germ-Free Mice to Antigenic Stimulation, Infect. Immun. 2 (1970) 96-100. 
[34] Rimoldi M., Rescigno M., Uptake and presentation of orally administered antigens, Vaccine 23 (2005) 1793-1796.

[35] Sato T., Nishimura-Uemura J., Shimosato T., Kawai Y., Kitazawa H., Saito T., Dextran from Leuconostoc mesenteroides augments immunostimulatory effects by the introduction of phosphate groups, J. Food Prot. 67 (2004) 1719-1729.

[36] Shaedler R.W., Dubos R., Costello R., Association of germ-free mice with bacteria isolated from normal mice, J. Exp. Med. 122 (1965) 77-93

[37] Shimosato T., Kitazawa H., Katoh S., Tomioka Y., Karima R., Ueha S., Kawai Y., Hishinuma T., Matsushima K., Saito T., Swine Toll-like receptor 9 recognizes $\mathrm{CpG}$ motifs of human cell stimulant, Biochim. Biophys. Acta 1627 (2003) 56-61.

[38] Shimosato T., Kitazawa H., Tohno M., Katoh S., Kawai Y., Saito T., Development of immune assay system for both $\mathrm{CpG}$ and nonCpG DNA from lactic acid bacteria using a transfectant of swine Toll-like receptor 9 , Anim. Sci. J. 75 (2004) 377-382.

[39] Shimosato T., Kitazawa H., Katoh S., Tohno M., Iliev I.D., Nagasawa C., Kimura T., Kawai Y., Saito T., Augmentation of T(H)-1 type response by immunoactive AT oligonucleotide from lactic acid bacteria via Tolllike receptor 9 signaling, Biochem. Biophys. Res. Commun. 326 (2005) 782-787.

[40] Shimosato T., Tohno M., Kitazawa H., Katoh S., Watanabe K., Kawai Y., Aso H., Yamaguchi T., Saito T., Toll-like receptor 9 is expressed on follicle-associated epithelia containing M cells in swine Peyer's patches, Immunol. Lett. 98 (2005) 83-89.

[41] Shimosato T., Kimura T., Tohno M., Iliev I.D., Katoh S., Ito Y., Kawai Y., Sasaki T., Saito T., Kitazawa H., Strong immunostimulatory activity of AT-oligodeoxynucleotide requires a six-base loop with a self-stabilized 5'-C...G-3' stem structure, Cell. Microbiol. 8 (2006) 485-495.

[42] Solano-Aguilar G.I., Vengroski K.G., Beshah E., Lunney J.K., Isolation and purification of lymphocyte subsets from gut-associated lymphoid tissue in neonatal swine, J. Immunol. Methods 241 (2000) 185-199.
[43] Solano-Aguilar G.I., Vengroski K.G., Beshah E., Douglass L.W., Lunney J.K., Characterization of lymphocyte subsets from mucosal tissues in neonatal swine, Dev. Comp. Immunol. 25 (2001) 245-263.

[44] Stefanini M., De Martino C., Zamboni L., Fixation of ejaculated spermatozoa for electron microscopy, Nature 216 (1967) 173-174.

[45] Takeda K., Saito T., Kitazawa H., Uemura J., Itoh T., Mitogenic activity of whole cells and cell wall components of Lactobacillus acidophilus group lactic acid bacteria on murine spleen and Peyer's patch cells, Milchwissenshaft 52 (1997) 21-25.

[46] Takeda K., Kaisho T., Akira S., Toll-like receptors, Annu. Rev. Immunol. 21 (2003) 335-376.

[47] Tohno M., Kitazawa H., Shimosato T., Matsumoto M., Katoh S., Kawai Y., Saito T., A swine toll-like receptor 2-expressing transfectant as a potential primary screening system for immunobiotic microorganisms, FEMS Immunol. Med. Microbiol. 44 (2005) 283-288.

[48] Tohno M., Shimosato T., Kitazawa H., Katoh S., Iliev I.D., Kimura T., Kawai Y., Watanabe K., Aso H., Yamaguchi T., Saito T., Tolllike receptor 2 is expressed on the intestinal $\mathrm{M}$ cells in swine, Biochem. Biophys. Res. Commun. 330 (2005) 547-554.

[49] Underhill D.M., Ozinsky A., Hajjar A.M., Stevens A., Wilson C.B., Bassetti M., Aderem A., The Toll-like receptor 2 is recruited to macrophage phagosomes and discriminates between pathogens, Nature 401 (1999) 811-815

[50] Underhill D.M., Macrophage recognition of zymosan particles, J. Endotoxin Res. 9 (2003) 176-180.

[51] Van der Stede Y., Verdonck F., Vancaeneghem S., Cox E., Goddeeris B.M., CpG-oligodinucleotides as an effective adjuvant in pigs for intramuscular immunizations, Vet. Immunol. Immunopathol. 86 (2002) 31-41.

[52] Veis D.J., Sentman C.L., Bach E.A., Korsmeyer S.J., Expression of the Bcl-2 protein in murine and human thymocytes and in peripheral T lymphocytes, J. Immunol. 151 (1993) 2546-2554. 